\title{
Laparotomy vs. minimally invasive surgery for ovarian cancer recurrence: a systematic review
}

\author{
Stefano Uccella ${ }^{1,2}$, Massimo P. Franchi ${ }^{2}$, Stefano Cianci ${ }^{3}$, Pier Carlo Zorzato ${ }^{1,2}$, Francesca Bertoli ${ }^{4}$, \\ Salvatore Gueli Alletti ${ }^{5}$, Fabio Ghezzi ${ }^{4}$, Giovanni Scambia ${ }^{5}$
}

${ }^{1}$ Division of Obstetrics and Gynecology, Department of Maternal, Neonatal and Infant Health, ASL Biella, Italy; ${ }^{2}$ Department of Obstetrics and Gynecology, University of Verona, Verona, Italy; ${ }^{3}$ Department of Woman Child and General and Specialized Surgery, University of Campania "Luigi Vanvitelli”, Naples, Italy; ${ }^{4}$ Department of Obstetrics and Gynecology, University of Insubria, F. Del Ponte Hospital, Varese, Italy; ${ }^{5}$ Fondazione Policlinico Universitario A. Gemelli IRCCS, Dipartimento Scienze della Salute della Donna, del Bambino e di Sanità Pubblica, UOC di Ginecologia Oncologica, Università Cattolica Del Sacro Cuore, Roma, Italy

Contributions: (I) Conception and design: S Uccella, S Cianci, SG Alletti; (II) Administrative support: S Uccella, MP Franchi, F Ghezzi, G Scambia; (III) Provision of study materials or patients: S Uccella, F Bertoli; (IV) Collection and assembly of data: S Uccella, PC Zorzato, F Bertoli; (V) Data analysis and interpretation: S Uccella, S Cianci, SG Alletti; (VI) Manuscript writing: All authors; (VII) Final approval of manuscript: All authors.

Correspondence to: Stefano Uccella, MD, PhD. Division of Obstetrics and Gynecology, Department of Maternal, Neonatal and Infant Health, Via dei Ponderanesi, 2 - Ponderano, Biella, Italy. Email: stefucc@libero.it.

\begin{abstract}
The objective of the present review is to thoroughly investigate the role of minimally invasive surgery (MIS) in the setting of secondary cytoreduction for ovarian cancer recurrence, comparing this approach to traditional open surgery. PubMed, ClinicalTrials.gov, Scopus and Web of Science databases (between 1st January 1989 and 1st January 2020), have been systematically queried to identify all articles reporting either laparoscopic or robotic-assisted secondary surgical cytoreduction for recurrent ovarian cancer. We also manually searched the reference lists of the identified studies. Only English language papers were considered. Two independent reviewers screened and identified the reports. A sub-analysis was performed including studies comparing MIS vs. open abdominal secondary cytoreduction. A total of 617 articles were considered. Among them, we included 12 retrospective studies on minimally invasive secondary cytoreduction, enrolling 372 patients (260 of whom were submitted to whether robotics or laparosopy). Three studies compared 69 patients who underwent MIS vs. 112 cases of open abdominal secondary cytoreduction. Other 9 articles described a total of 191 patients who had minimally invasive secondary cytoreduction for recurrent ovarian cancer without a comparative arm. The quality of the evidence was low. The decision regarding the use of MIS was left to surgeon's discretion; in general, the candidates to MIS were selected patients with single-site disease or few localizations of relapse. Compared to open surgery, MIS was associated with significantly lower blood loss, shorter hospital stay and less postoperative complications; the rate of complete cytoreduction to residual tumor $=0$ was $95.5 \%$ in MIS cases $v$ s. $87.5 \%$ in laparotomy cases. The risk of complications was generally low. Disease-free and overall survival were comparable between groups. There is no consensus on the criteria to select patients for laparoscopic or robotic secondary cytoreduction. Intra-operative ultrasound has been proposed as a possible tool to better identify the site of recurrence and for confirmation of complete resection of disease. In conclusion, MIS is an option in selected patients with recurrent ovarian cancer, provided there is no widespread disease. Selection of patients appears of utmost importance to obtain satisfactory survival outcomes.
\end{abstract}

Keywords: Ovarian cancer; relapse; minimally invasive surgery (MIS); laparoscopy; robotics; open surgery

Submitted Mar 14, 2020. Accepted for publication Jul 15, 2020.

doi: $10.21037 /$ gs-20-353

View this article at: http://dx.doi.org/10.21037/gs-20-353 


\section{Introduction}

Ovarian cancer represents the most lethal malignancy of the female genital tract (1). Even in cases of optimal initial treatment, the majority of the affected patients will experience a relapse (2), and the probability of recurrence is almost certain in case of advanced-stage disease at initial diagnosis.

Retrospective reports have strongly suggested that, in case of recurrence of ovarian cancer, radical secondary cytoreduction is beneficial to the patients and prolongs survival if no macroscopic disease is left at the end of surgery $(3-7)$. These assumptions have been recently questioned by a large randomized trial promoted by the Gynecologic Oncology Group (GOG-213), in which the benefit of secondary surgery was only on disease-free survival and not on overall survival (8). The results of the GOG-213 have been strongly criticized, mainly because of the low rate of complete cytoreduction $(63 \%)$ in patients assigned to secondary surgical effort. In 2018, the preliminary results of another randomized trial (the DESKTOP-3) have been presented at the ASCO meeting (9): with a higher rate of complete surgical eradication (74\%) the trial showed a survival advantage of a secondary surgical effort in patients with ovarian cancer relapse. However, data from this trial are still immature and final reports are awaited.

A relevant and partially different issue is the occurrence of lymphatic relapses: the complete eradication of them has been shown to be associated with a substantial improvement in patients' prognosis and represents a widely accepted indication to perform surgery (10-12).

Regardless of all the debates on these topics, surgical secondary cytoreduction (SSC) is considered an important option in case of ovarian cancer recurrence (3). As for upfront surgery, the possibility to perform SSC by laparoscopy or robotics has been taken into consideration because of the well-known beneficial effects of minimallyinvasive surgery on intra-operative blood-loss, risk of transfusions, rate of peri-operative complications and postoperative recover, including a shorter time to initiation of adjuvant chemotherapy (13-29). Few reports have investigated the role of minimally invasive SSC, and even less have compared endoscopic techniques to traditional open surgery $(10,30,31)$. The aim of this review has been to investigate in depth the role of minimally invasive surgery (MIS) in the setting of secondary cytoreduction in case of ovarian cancer recurrence, and to summarize the available evidence and possible indications for MIS in this setting. We present the following article in accordance with the PRISMA reporting checklist (available at http://dx.doi. org/10.21037/gs-20-353).

\section{Methods}

This review was performed according to the PRISMA statement and was registered in the PROSPERO register (CRD42020173156).

A reference librarian with expertise in electronic search strategies for systematic reviews conducted the literature search in conjunction with a senior gynecologist (SU). PubMed, ClinicalTrials.gov, Scopus and Web of Science databases were systematically searched for records from January 1st 1989, to January 1st 2020.

No institutional review board approval was required, because the present study deals with already existing data. All authors participated in the search strategy design and in the definition of the inclusion and exclusion criteria.

The final literature search was performed in February 2020, using the following strings: "ovarian neoplasm" or "ovarian cancer" or "ovarian malignancy" AND "secondary cytoreduction" or "recurrence" or "relapse" or "failure" and "laparoscopy" or "robotics" or "minimally-invasive surgery".

Eligibility assessment was performed independently by two reviewers (SU, PCZ). All pertinent articles were carefully evaluated. Full manuscripts were obtained for all selected articles, and the decision for final inclusion was made after a detailed examination of the paper. To avoid missing any relevant publication, a manual search of the reference lists of the retrieved studies and review articles was performed. We included only studies written in English and describing the use of laparoscopy or robotics for secondary surgical cytoreduction for recurrent ovarian cancer. Abstract at conferences not followed by full-text articles were not considered. Published cases incorporated in subsequent series were excluded. Only cases of secondary cytoreduction were included (therefore cases of tertiary or quaternary cytoreduction were excluded). In case of any disagreement between the two reviewers regarding the inclusion of studies, a third author (MPF) was asked to take the final decision.

The same authors independently extracted data from the articles. The quality of the included studies was graded according to the Grading of Recommendations, Assessment Development, and Evaluation system (32). The Grading 


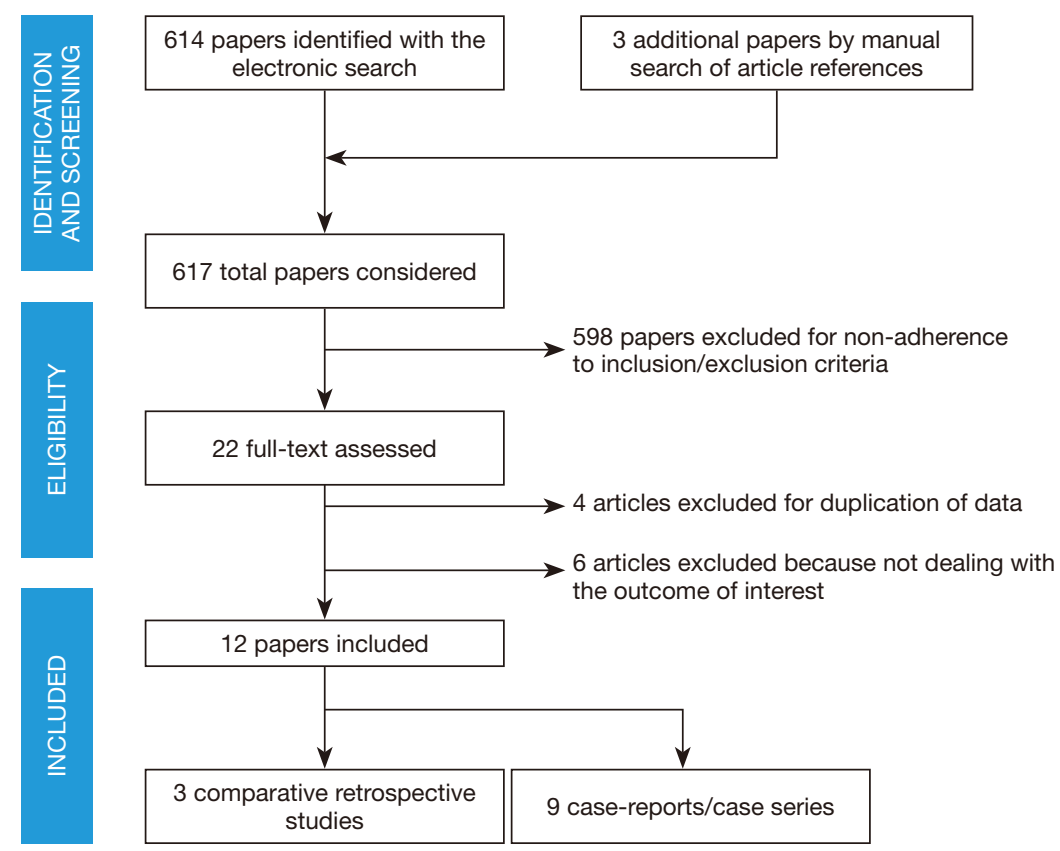

Figure 1 PRISMA diagram-transparent reporting of systematic reviews and meta-analysis flow diagram outlining the search strategy results from initial search to included studies.

of Recommendations, Assessment, Development, and Evaluation Working Group classifies the quality of studies as follows: high quality (further research is very unlikely to change our confidence in the estimate of effect), moderate quality (further research is likely to have an important impact on our confidence in the estimate of effect and may change the estimate), low quality (further research is very likely to have an important impact on our confidence in the estimate of effect and is likely to change the estimate), and very low quality (we are very uncertain about the estimate).

Only studies including patients with epithelial ovarian malignancies were considered. The literature search (Figure 1), based on our predefined key search items, identified 617 publications after adjusting for duplicates.

\section{Main review outcomes}

(I) To summarize the available reports regarding the outcomes of MIS (whether laparoscopic or robotic) compared to traditional open surgery;

(II) to summarize the articles describing the use of MIS in the setting of SSC for recurrent ovarian cancer;

(III) to provide possible strategies to select patients for minimally invasive secondary cytoreduction and to improve outcomes.

\section{Statistical analysis}

Categorical data are presented as absolute number (percentage). Continuous data are presented as mean \pm standard deviation or median (range). The chi square test was used to calculate $\mathrm{P}$ values of the comparison of MIS $v$. open surgery in case of categorical variables.

\section{Results}

A total of 12 articles including 372 patients were identified. Three studies compared 69 patients who underwent MIS SSC vs. 112 cases of open abdominal SSC. Other 9 articles described a total of 191 patients who had minimally invasive secondary cytoreduction for recurrent ovarian cancer without comparison with traditional open treatment. Overall, the number of patients reported in the literature who received MIS debulking for relapse of ovarian cancer is 260.

The quality of the evidence is definitely low, being based on 3 retrospective comparative studies, 6 retrospective case series and 3 case reports. In all cases, only selected patients underwent MIS for SSC. No clear criteria to identify cases suitable for laparoscopic or robotic debulking were adopted and the decision was left to surgeon's discretion; in general, 
Table 1 Characteristics of the study included

\begin{tabular}{|c|c|c|c|c|c|c|c|}
\hline Study & Study design & $\begin{array}{l}\text { Quality of } \\
\text { evidence }\end{array}$ & $\begin{array}{c}\text { Selection of } \\
\text { patients for MIS }\end{array}$ & $\begin{array}{c}\text { Choice of MIS } \\
\text { approach }\end{array}$ & Nr. of patients & $\begin{array}{l}\text { Follow-up } \\
\text { (months) }\end{array}$ & Notes \\
\hline $\begin{array}{l}\text { Magrina et al. } \\
\text { [2013] (35) }\end{array}$ & Retrospective & Low & Yes & $\begin{array}{l}\text { Surgeon's } \\
\text { discretion }\end{array}$ & $\begin{array}{l}\text { LPS: 9; LPT: 33; } \\
\text { Robot: } 10\end{array}$ & $>3$ years & \\
\hline $\begin{array}{l}\text { Fagotti et al. } \\
(2015)(33)\end{array}$ & Retrospective & Low & Yes & $\begin{array}{l}\text { Surgeon's } \\
\text { discretion }\end{array}$ & $\begin{array}{c}\text { MIS: 11; LPT: } \\
11\end{array}$ & Not available & $\begin{array}{l}\text { Use of HIPEC at the } \\
\text { end of the procedure }\end{array}$ \\
\hline Total & All retrospective & Low & All & $\begin{array}{l}\text { Surgeon's } \\
\text { discretion }\end{array}$ & $\begin{array}{c}\text { MIS: 69; LPT: } \\
112\end{array}$ & Variable & / \\
\hline
\end{tabular}

LPS, laparoscopy; LPT, laparotomy; MIS, minimally invasive surgery.

Table 2 Operative procedures

\begin{tabular}{|c|c|c|c|c|c|c|}
\hline Study & Liver resection & Bowel resection & $\begin{array}{l}\text { Diaphragmatic } \\
\text { resection }\end{array}$ & $\begin{array}{l}\text { Peritoneal abdominal } \\
\text { carcinosis resection }\end{array}$ & $\begin{array}{l}\text { Ureter/Bladder } \\
\text { resection }\end{array}$ & Lymphadenectomy \\
\hline $\begin{array}{l}\text { Magrina et al. } \\
\text { [2013] (35) }\end{array}$ & $\begin{array}{l}\text { LPS } 1(11.1 \%) ; \\
\text { LPT } 5 \text { (15.2\%); } \\
\text { Robot } 5(50 \%)\end{array}$ & $\begin{array}{l}\text { LPS } 1(11.1 \%) ; \\
\text { LPT } 21(63.6 \%) ; \\
\text { Robot } 3(30 \%)\end{array}$ & $\begin{array}{l}\text { LPS } 3(33.3 \%) ; \\
\text { LPT } 6(18.2 \%) ; \\
\text { Robot } 5(50 \%)\end{array}$ & $\begin{array}{l}\text { LPS } 6 \text { (66.6\%); LPT } \\
31(93.7 \%) ; \text { Robot } 9 \\
(90 \%)\end{array}$ & $\begin{array}{l}\text { LPS 0; LPT } 2 \\
(6.1 \%) ; \text { Robot } 1 \\
(10 \%)\end{array}$ & $\begin{array}{l}\text { LPS } 2(22.2 \%) ; \\
\text { LPT } 13(39.4 \%) ; \\
\text { Robot } 6(60 \%)\end{array}$ \\
\hline $\begin{array}{l}\text { Fagotti et al. } \\
\text { [2015] (33) }\end{array}$ & MIS 0; LPT 0 & $\begin{array}{l}\text { MIS } 3(27.3 \%) \\
\text { LPT } 1(9.1 \%)\end{array}$ & $\begin{array}{l}\text { MIS 0; LPT } 3 \\
(27.3 \%)\end{array}$ & $\begin{array}{l}\text { MIS } 8 \text { (72.7\%); LPT } \\
7(63.6 \%)\end{array}$ & MIS 0; LPT 0 & MIS 0; LPT 0 \\
\hline $\begin{array}{l}\text { Eriksson et al. } \\
\text { [2019] (36) }\end{array}$ & MIS 0; LPT 0 & $\begin{array}{l}\text { MIS } 9 \text { (23\%); } \\
\text { LPT } 22(32 \%)\end{array}$ & Not available & Not available & Not available & Not available \\
\hline
\end{tabular}

we noticed that the candidates to MIS had single-site disease or few localizations of relapse. Only 3 studies $(31,33,34)$ provided details regarding the performance status of patients included; when mentioned, only patients in good performance status (0 to 2 ) were included.

\section{Studies comparing SSC by MIS vs. laparotomy (Tables 1-4)}

The three available studies comparing MIS to open surgery included both cases of laparoscopic and robotic SSC $(33,35,36)$. Two of the three studies provided oncological outcomes $(35,36)$. The study by Eriksson et al. (36) did not describe in detail the type of surgical procedures performed.

MIS is associated with significantly lower blood loss, shorter hospital stay and less postoperative complications. Of note, the surgical effort appears less extended in the MIS group. Complete cytoreduction to residual tumor $=0$ was overall achieved in $95.5 \%$ of MIS cases $v s .87 .5 \%$ of laparotomy cases in the three studies. Disease-free and overall survival were comparable between groups: in the study by Magrina et al. the 3-year disease-free survival was
$22.9 \%$ for laparoscopic surgery, $33.1 \%$ for laparotomy and $43.8 \%$ for robotics $(\mathrm{P}=0.95)$, while the 3 -year overall survival was $66.7 \%, 48.4 \%$ and $85.7 \%$, respectively; in the study by Eriksson et al. the 2-year disease-free survival was $56.1 \%$ for MIS vs. $63.5 \%$ for laparotomy and the 2-year overall survival was $92.2 \%$ and $81.4 \%$ for MIS and laparotomy, respectively.

\section{Case series and case reports describing robotic or laparoscopic SSC (Table 5)}

Nine reports for a total of 120 laparoscopic and 71 robotic cases of SSC have been described in non-comparative literature (10,31,34,37-42). Several types of surgical procedures have been reported, including liver resection, bowel resection, diaphragmatic resection, splenectomy, and extended peritoneal stripping. The rate of complete cytoreduction to no residual tumor is high $(91.6 \%)$ and the risk of complications is low $11.5 \%$.

Survival outcomes, although limited by the study design and possible reporting bias, are extremely encouraging, with 
Table 3 Perioperative outcomes

\begin{tabular}{|c|c|c|c|c|c|}
\hline Study & Operative time (min) & Blood loss (mL) & Hospital stay (days) & $\begin{array}{l}\text { Intraoperative } \\
\text { complications }\end{array}$ & $\begin{array}{l}\text { Postoperative } \\
\text { complications }\end{array}$ \\
\hline $\begin{array}{l}\text { Magrina et al. } \\
\text { [2013] (35) }\end{array}$ & $\begin{array}{l}\text { LPS } 167 \text { [61-320]; } \\
\text { LPT } 219 \text { [75-492]; } \\
\text { Robot } 247 \text { [75-465]; } \\
(P=0.33)\end{array}$ & $\begin{array}{l}\text { LPS } 100 \text { [0-500]; } \\
\text { LPT } 675[20-3,000] ; \\
\text { Robot } 100[50-800] ; \\
(P<0.0001)\end{array}$ & $\begin{array}{l}\text { LPS } 2 \text { [1-19]; LPT } \\
7 \text { [3-35]; Robot } 2.5 \\
{[1-7] ;(P=0.0002)}\end{array}$ & $\begin{array}{l}\text { LPS } 2(22.2 \%) ; \\
\text { LPT } 7(21.2 \%) ; \\
\text { Robot } 1(10 \%) ; \\
(P=0.77)\end{array}$ & $\begin{array}{l}\text { LPS } 3(33.3 \%) ; \\
\text { LPT } 14(42.4 \%) ; \\
\text { Robot } 2(20 \%) ; \\
(P=0.46)\end{array}$ \\
\hline $\begin{array}{l}\text { Eriksson et al. } \\
\text { [2019] (36) }\end{array}$ & $\begin{array}{l}\text { MIS } 186 \text { [56-482]; LPT } \\
216 \text { [64-539]; }(P=0.2)\end{array}$ & $\begin{array}{l}\text { MIS } 50 \text { [5-500]; } \\
\text { LPT } 150[0-1,500] \\
(P=0.001)\end{array}$ & $\begin{array}{l}\text { MIS 1 [1-23]; LPT } 5 \\
{[1-21] ;(P=0.001)}\end{array}$ & MIS 0; LPT 0 & $\begin{array}{l}\text { MIS } 3(8 \%) ; \\
\text { LPT } 15(22 \%) ; \\
(P=0.06)\end{array}$ \\
\hline
\end{tabular}

Table 4 Survival outcomes

\begin{tabular}{|c|c|c|c|}
\hline Study & $\begin{array}{l}\text { Complete cytoreduction (residual } \\
\text { tumor }=0 \text { ) }\end{array}$ & Progression-free survival & Overall survival \\
\hline Magrina et al. [2013] (35) & $\begin{array}{l}\text { LPS } 8 \text { (88.9\%); LPT } 24 \text { (72.7\%); } \\
\text { Robot } 7 \text { (70\%); (P=0.66) }\end{array}$ & $\begin{array}{l}\text { 3-year: LPS } 22.9 \% \text {; LPT } 33.1 \% \text {; } \\
\text { Robot } 43.8 \% ;(P=0.95)\end{array}$ & $\begin{array}{l}\text { 3-year: LPS } 66.7 \% \text {; LPT } 48.4 \% \text {; } \\
\text { Robot } 85.7 \% ;(P=0.18)\end{array}$ \\
\hline Fagotti et al. [2015] (33) & $\begin{array}{l}\text { MIS } 11(100 \%) ; \text { LPT } 11(100 \%) \\
(P=1.00)\end{array}$ & Not available & Not available \\
\hline Total & $\begin{array}{l}\text { MIS } 63 \text { (95.5\%); LPT } 98 \text { (87.5\%); } \\
(\mathrm{P}=0.81)\end{array}$ & - & - \\
\hline
\end{tabular}

disease-free survival ranging between 13 and 71.9 months.

\section{Possible strategies to select patients and improve outcomes}

As mentioned, there is no consensus on the criteria to select patients for laparoscopic or robotic secondary cytoreduction. However, all the available series point out that only localized disease is suitable for MIS approach. Ideally, a diagnostic laparoscopy, combined with preoperative imaging may provide adequate evaluation of the peritoneal cavity to confirm or discourage MIS (43).

Intra-operative ultrasound has been proposed as a possible tool for better identification of localizations and recurrence of ovarian cancer and for improved tailoring of SSC $(44,45)$. Mascilini et al. in 2018 have described a series of 51 MIS debulking procedures for recurrent ovarian cancer; among them, intraoperative ultrasound allowed proper identification of recurrence and confirmation of complete resection in $25 \%$ of cases, thus extending the applicability of minimally invasive technique and reducing the need for open surgery (44).

The summary of the evidence, with the main results of this review and the implications for research are summarized in Table 6.

\section{Discussion}

The present review shows that MIS in selected cases is an option for secondary cytoreduction in recurrent ovarian cancer. In cases of localized relapses, laparoscopic and robotic approaches provide improved peri-operative outcomes and, apparently, satisfactory survival outcomes. 
Table 5 Non-comparative studies (laparoscopic and robotic surgery)

\begin{tabular}{|c|c|c|c|c|c|c|}
\hline Study & $\begin{array}{l}\text { Type of study/ } \\
\text { approach }\end{array}$ & $\begin{array}{c}\mathrm{Nr} \text { of } \\
\text { patients }\end{array}$ & Procedures & $\begin{array}{l}\text { Complete } \\
\text { cytoreduction }\end{array}$ & Complications & Follow-up \\
\hline $\begin{array}{l}\text { Trinh et al. } \\
2004 \text { (37) }\end{array}$ & $\begin{array}{l}\text { Retrospective/ } \\
\text { LPS }\end{array}$ & 34 & $\begin{array}{l}\text { Peritonectomy with LEEP + } \\
\text { Argon Beam: } 34\end{array}$ & 32/34 (96\%) & $2 / 34(5.9 \%)$ & $\begin{array}{l}\text { Disease-free } \\
\text { survival: } 13 \text { months }\end{array}$ \\
\hline $\begin{array}{l}\text { Holloway et al. } \\
2011 \text { (38) }\end{array}$ & $\begin{array}{l}\text { Case report/ } \\
\text { ROBOT }\end{array}$ & 1 & $\begin{array}{l}\text { Liver Resection + } \\
\text { Diaphrapgm resection: } 1\end{array}$ & $1 / 1(100 \%)$ & $1 / 1(100 \%)$ & Not available \\
\hline $\begin{array}{l}\text { Nezhat et al. } \\
2014(39)\end{array}$ & $\begin{array}{l}\text { Retrospective/ } \\
\text { ROBOT }\end{array}$ & 4 & Not available & $4 / 4(100 \%)$ & Not available & Not available \\
\hline $\begin{array}{l}\text { Gallotta et al. } \\
2018(31)\end{array}$ & $\begin{array}{l}\text { Retrospective/ } \\
\text { LPS }\end{array}$ & 58 & $\begin{array}{l}\text { Lymphadenectomy: } \\
\text { 24; Peritonectomy: 28; } \\
\text { Rectosigmoid resection: } \\
\text { 1; Colpectomy: 1; Radical } \\
\text { omentectomies: 3; } \\
\text { Splenectomy: 5; Liver } \\
\text { resection: } 1\end{array}$ & $58 / 58(100 \%)$ & $10 / 58(17.2 \%)$ & $\begin{array}{l}\text { Disease-free } \\
\text { survival: } 28 \text { months }\end{array}$ \\
\hline $\begin{array}{l}\text { Uccella et al. } \\
2019(10)\end{array}$ & $\begin{array}{l}\text { Case report/ } \\
\text { LPS }\end{array}$ & 1 & $\begin{array}{l}\text { Retroaortic } \\
\text { lymphadenectomy: } 1\end{array}$ & $1 / 1(100 \%)$ & 0 & $\begin{array}{l}\text { NED after } 14 \\
\text { months }\end{array}$ \\
\hline Total & Retrospective & 191 & Various & $\begin{array}{l}175 / 191 \\
(91.6 \%)\end{array}$ & $\begin{array}{l}22 / 191 \\
(11.5 \%)\end{array}$ & $\begin{array}{c}\text { DFS: } 13-71.9 \\
\text { months }\end{array}$ \\
\hline
\end{tabular}

LEEP, loop electrosurgical excisional procedure; NED, no evidence of disease at last follow-up; DFS, disease-free survival.

MIS has been proposed for more than one decade in the treatment of both early and advanced ovarian cancer at the time of primary diagnosis (13-24). Interestingly, the role of laparoscopy appears crucial in the development of new strategies such as sentinel node biopsy for disease macroscopically limited to the ovary at upfront surgery $(13,15,17-19)$. Although much less investigated, laparoscopic and robotic surgery have been used also in complex procedures for primary interval debulking surgery (14).
The use of MIS in secondary cytoreduction has been very scarcely explored and the available evidence is of low quality. The reasons for this paucity of data is due to: (I) uncertainties regarding the role of secondary surgical cytoreduction in ovarian cancer; (II) the technical difficulties of MIS in this setting; (III) unclear criteria to select patients.

Surgery for advanced ovarian cancer is associated with a high risk of complications due to the widespread disease and the poor preoperative nutritional status of the patient 
Table 6 Main results of the review and implications for research

Main results: the present review shows that

(I) Minimally invasive Surgery is an option in selected cases with localized or not widespread recurrent ovarian cancer

(II) Selection of patients is of utmost importance to obtain complete cytoreduction and adequate survival outcomes

Limitations: the literature on this issue is very scant and based on case reports and case series or retrospective comparisons with traditional open surgery

Implications for future research: the efforts of researchers should be focused on:

(I) Providing more reliable evidence on the real impact of minimally invasive surgery on survival outcomes, with prospective, comparative possibly randomized trials

(II) Another important aspect is the identification of reliable tools to select patients for minimally invasive secondary surgical cytoreduction. The development of a score, possibly including a diagnostic laparoscopy may be useful

(III) The implementation of intraoperative ultrasound should be further tested in order to understand its possible benefits in terms of correct identification of the site of recurrence and confirmation of complete disease resection

(46-50). In case of recurrent ovarian cancer with localized relapses, MIS may at least theoretically be of great benefit to the patients, because it reduces the surgical trauma and enhances recovery after surgery. A particular subset of patients who may benefit more from MIS approach is represented by subjects with lymphatic failure. Outcomes in this particular subset of patients appear extremely favorable both in terms of peri-operative results and long-term survival $(10,43,51)$.

The use of pre-operative laparoscopic exploration and intra-operative ultrasound may enhance the ability to select patients and, at the same time, may improve the ability to radically resect the disease without opening the abdomen with a wide surgical incision (43).

Inevitably, MIS requires a high level of expertise and skills when applied to the field of recurrent ovarian cancer and it should be performed only in oncological centers with adequate background in complex surgical procedures.

The present review has two main limitations:

(I) The inherent bias deriving from the type of the studies included. No randomized trials are available and the cases undergoing MIS are inevitably more favorable than those submitted to laparotomy. This imbalance negatively affects the conclusions of the published series. The reduced amount of evidence as well as its low quality should encourage researchers to adopt this approach in the context of welldesigned, possibly prospective clinical trials, in order to provide more reliable knowledge on this issue.

(II) The exclusion of articles dealing with tertiary or quaternary MIS cytoreduction. However, the number of cases in which MIS was adopted for second or third relapse of ovarian cancer was so low that it may be regarded as anecdotical.

In conclusion, ovarian cancer still represents a difficult diagnostic and therapeutical challenge (52). MIS should be considered as a possible alternative to laparotomy for SSC of recurrent ovarian cancer in highly selected cases, at dedicated oncological centers and possibly in the context of well-conducted scientific research.

\section{Acknowledgments}

Funding: None.

\section{Footnote}

Provenance and Peer Review: The article was commissioned by the editorial office, Gland Surgery for the series "Ovarian Cancer Recurrence". The article has undergone external peer review.

Reporting Checklist: The authors have completed the PRISMA reporting checklist. Available at http://dx.doi. org/10.21037/gs-20-353

Conflicts of Interest: All authors have completed the ICMJE uniform disclosure form (available at http://dx.doi. org/10.21037/gs-20-353). The series "Ovarian Cancer Recurrence" was commissioned by the editorial office without any funding or sponsorship. SC serves as an unpaid editorial board member of Gland Surgery from Aug 2019 to 
Jul 2021 and served as the unpaid Guest Editor of the series. The authors have no other conflicts of interest to declare.

Ethical Statement: The authors are accountable for all aspects of the work in ensuring that questions related to the accuracy or integrity of any part of the work are appropriately investigated and resolved.

Open Access Statement: This is an Open Access article distributed in accordance with the Creative Commons Attribution-NonCommercial-NoDerivs 4.0 International License (CC BY-NC-ND 4.0), which permits the noncommercial replication and distribution of the article with the strict proviso that no changes or edits are made and the original work is properly cited (including links to both the formal publication through the relevant DOI and the license). See: https://creativecommons.org/licenses/by-nc-nd/4.0/.

\section{References}

1. Siegel RL, Miller KD, Jemal A. Cancer statistics, 2020. CA Cancer J Clin 2020;70:7-30.

2. du Bois A, Reuss A, Pujade-Lauraine E, et al. Role of surgical outcome as prognostic factor in advanced epithelial ovarian cancer: a combined exploratory analysis of 3 prospectively randomized phase 3 multicenter trials: by the Arbeitsgemeinschaft Gynaekologische Onkologie Studiengruppe Ovarialkarzinom (AGO-OVAR) and the Groupe d'Investigateurs Nationaux Pour les Etudes des Cancers de l'Ovaire (GINECO). Cancer 2009;115:1234-44.

3. Colombo N, Sessa C, du Bois A, et al. ESMO-ESGO consensus conference recommendations on ovarian cancer: pathology and molecular biology, early and advanced stages, borderline tumours and recurrent disease $†$. Ann Oncol 2019;30:672-705.

4. Harter P, Sehouli J, Reuss A, et al. Prospective validation study of a predictive score for operability of recurrent ovarian cancer: the Multicenter Intergroup study DESKTOP II. A project of the AGO Kommission Annals of Oncology Special article doi:10.1093/annonc/mdz062 । 703 OVAR, AGO Study Group, NOGGO, AGO-Austria, and MITO. Int J Gynecol Cancer 2011;21:289-95.

5. Lee CK, Lord S, Grunewald T, et al. Impact of secondary cytoreductive surgery on survival in patients with platinum sensitive recurrent ovarian cancer: analysis of the CALYPSO trial. Gynecol Oncol 2015;136:18-24.

6. Fotopoulou C, Zang R, Gultekin M, et al. Value of tertiary cytoreductive surgery in epithelial ovarian cancer: an international multicenter evaluation. Ann Surg Oncol 2013;20:1348-54.

7. Cianci S, Ronsini C, Vizzielli G, et al. Cytoreductive surgery followed by HIPEC repetition for secondary ovarian cancer recurrence. Updates Surg 2019;71:389-94.

8. Coleman RL, Spirtos NM, Enserro D, et al. Secondary Surgical Cytoreduction for Recurrent Ovarian Cancer. N Engl J Med 2019;381:1929-39.

9. Du Bois A, Vergote I, Ferron G, et al. Randomized controlled phase III study evaluating the impact of secondary cytoreductive surgery in recurrent ovarian cancer: AGO DESKTOP III/ENGOT ov20. J Clin Oncol 2017:15S;5501.

10. Uccella S, Zorzato PC, Forliti E, et al. Laparoscopic Excision of a 5-cm Retroaortic Relapse of Ovarian Cancer. J Minim Invasive Gynecol 2020;27:1017-8.

11. Legge F, Petrillo M, Adamo V, et al. Epithelial ovarian cancer relapsing as isolated lymph node disease: natural history and clinical outcome. BMC Cancer 2008;8:367.

12. Gadducci A, Cosio S, Zola P, et al. The clinical outcome of epithelial ovarian cancer patients with apparently isolated lymph node recurrence: a multicenter retrospective Italian study. Gynecol Oncol 2010;116:358-63.

13. Tinelli R, Stomati M, Trojano G, et al. Laparoscopic treatment of ovarian granulosa cells tumor developed in the pelvic anterior preperitoneal space 20 years after laparotomic salpingo-oophorectomy: case report and review of literature. Gynecol Endocrinol 2020. [Epub ahead of print].

14. Scambia G, Nero C, Uccella S, et al. Sentinel-node biopsy in early stage ovarian cancer: a prospective multicentre study (SELLY). Int J Gynecol Cancer 2019;29:1437-9.

15. Gueli Alletti S, Vizzielli G, Lafuenti L, et al. SingleInstitution Propensity-Matched Study to Evaluate the Psychological Effect of Minimally Invasive Interval Debulking Surgery Versus Standard Laparotomic Treatment: From Body to Mind and Back. J Minim Invasive Gynecol 2018;25:816-22.

16. Uccella S, Zorzato PC, Lanzo G, et al. The role of sentinel node in early ovarian cancer: a systematic review. Minerva Med 2019;110:358-66.

17. Gueli Alletti S, Capozzi VA, Rosati A, et al. Laparoscopy vs. laparotomy for advanced ovarian cancer: a systematic review of the literature. Minerva Med 2019;110:341-57.

18. Uccella S, Nero C, Vizza E, et al. Sentinel-node biopsy in early-stage ovarian cancer: preliminary results of a prospective multicentre study (SELLY). Am J Obstet 
Gynecol 2019;221:324.e1-10.

19. Uccella S, Fagotti A, Zannoni GF, et al. Presumed early ovarian cancer with isolated tumor cells in para-aortic sentinel nodes. Int J Gynecol Cancer 2019;29:216-20.

20. Uccella S, Gisone B, Stevenazzi G, et al. Laparoscopic sentinel node detection with ICG for early ovarian cancer: Description of a technique and literature review. Eur J Obstet Gynecol Reprod Biol 2018;221:193-4.

21. Ceccaroni M, Roviglione G, Bruni F, et al. Laparoscopy for primary cytoreduction with multivisceral resections in advanced ovarian cancer: prospective validation. "The times they are a-changin"? Surg Endosc 2018;32:2026-37.

22. Ghezzi F, Cromi A, Fanfani F, et al. Laparoscopic fertilitysparing surgery for early ovarian epithelial cancer: A multiinstitutional experience. Gynecol Oncol 2016;141:461-5.

23. Gallotta V, Ghezzi F, Vizza E, et al. Laparoscopic Management of Ovarian Cancer Patients With Localized Carcinomatosis and Lymph Node Metastases: Results of a Retrospective Multi-institutional Series. J Minim Invasive Gynecol 2016;23:590-6.

24. Gallotta V, Ghezzi F, Vizza E, et al. Laparoscopic staging of apparent early stage ovarian cancer: results of a large, retrospective, multi-institutional series. Gynecol Oncol 2014;135:428-34.

25. Cromi A, Bogani G, Uccella S, et al. Laparoscopic fertility-sparing surgery for early stage ovarian cancer: a single-centre case series and systematic literature review. J Ovarian Res 2014;7:59.

26. Ghezzi F, Malzoni M, Vizza E, et al. Laparoscopic staging of early ovarian cancer: results of a multi-institutional cohort study. Ann Surg Oncol 2012;19:1589-94.

27. Ghezzi F, Cromi A, Uccella S, et al. Incorporating laparoscopy in the practice of a gynecologic oncology service: actual impact beyond clinical trials data. Ann Surg Oncol 2009;16:2305-14.

28. Ghezzi F, Cromi A, Bergamini V, et al. Should adnexal mass size influence surgical approach? A series of 186 laparoscopically managed large adnexal masses. BJOG 2008;115:1020-7.

29. Uccella S, Cromi A, Seveso A, et al. Comprehensive laparoscopic surgical staging of ovarian dysgerminoma in a 13-year-old girl: a case report. J Minim Invasive Gynecol 2008;15:110-2.

30. Ghezzi F, Cromi A, Uccella S, et al. Laparoscopy versus laparotomy for the surgical management of apparent early stage ovarian cancer. Gynecol Oncol 2007;105:409-13.

31. Gallotta V, Conte C, Giudice MT, et al. Secondary Laparoscopic Cytoreduction in Recurrent Ovarian Cancer:
A Large, Single-Institution Experience. J Minim Invasive Gynecol 2018;25:644-50.

32. Guyatt GH, Oxman AD, Vist GE, et al. GRADE: an emerging consensus on rating quality of evidence and strength of recommendations. BMJ 2008;336:924-6.

33. Fagotti A, Costantini B, Gallotta V, et al. Minimally invasive secondary cytoreduction plus HIPEC versus open surgery plus HIPEC in isolated relapse from ovarian cancer: a retrospective cohort study on perioperative outcomes. J Minim Invasive Gynecol 2015;22:428-32.

34. Nezhat FR, Denoble SM, Cho JE, et al. Safety and efficacy of video laparoscopic surgical debulking of recurrent ovarian, fallopian tube, and primary peritoneal cancers. JSLS 2012;16:511-8.

35. Magrina JF, Cetta RL, Chang YH, et al. Analysis of secondary cytoreduction for recurrent ovarian cancer by robotics, laparoscopy and laparotomy. Gynecol Oncol 2013;129:336-40.

36. Eriksson AGZ, Graul A, Yu MC, et al. Minimal access surgery compared to laparotomy for secondary surgical cytoreduction in patients with recurrent ovarian carcinoma: Perioperative and oncologic outcomes. Gynecol Oncol 2017;146:263-7.

37. Trinh H, Ott C, Fanning J. Feasibility of laparoscopic debulking with electrosurgical loop excision procedure and argon beam coagulator at recurrence in patients with previous laparotomy debulking. Am J Obstet Gynecol 2004;190:1394-7.

38. Holloway RW, Brudie LA, Rakowski JA, et al. Roboticassisted resection of liver and diaphragm recurrent ovarian carcinoma: description of technique. Gynecol Oncol 2011;120:419-22.

39. Nezhat FR, Finger TN, Vetere P, et al. Comparison of perioperative outcomes and complication rates between conventional versus robotic-assisted laparoscopy in the evaluation and management of early, advanced, and recurrent stage ovarian, fallopian tube, and primary peritoneal cancer. Int J Gynecol Cancer 2014;24:600-7.

40. Mutlu L, Khadraoui W, Khader T, et al. Robotic Tumor Debulking off External Iliac Vessels for the Management of Recurrent Ovarian Cancer. J Minim Invasive Gynecol 2020;27:1021-2.

41. Magrina JF, Guardiola TC, Magtibay PM 3rd, et al. Minimally Invasive Surgery for Resection of Diaphragm Metastases in Ovarian Cancer. J Minim Invasive Gynecol 2019;26:1268-72.

42. Yang W, Cheng Z, Dai H, et al. Laparoscopic-based score assessment combined with a multiple disciplinary team 
in management of recurrent ovarian cancer: A singlecenter prospective study for personalized surgical therapy. Medicine (Baltimore) 2017;96:e7440.

43. Mascilini F, Quagliozzi L, Moro F, et al. Role of Intraoperative Ultrasound to Extend the Application of Minimally Invasive Surgery for Treatment of Recurrent Gynecologic Cancer. J Minim Invasive Gynecol 2018;25:848-54.

44. Moro F, Uccella S, Testa AC, et al. Intraoperative Ultrasound-Guided Excision of Cardiophrenic Lymph Nodes in an Advanced Ovarian Cancer Patient. Int J Gynecol Cancer 2018;28:1672-5.

45. Uccella S, Mele MC, Quagliozzi L, et al. Assessment of preoperative nutritional status using BIA-derived phase angle $(\mathrm{PhA})$ in patients with advanced ovarian cancer: Correlation with the extent of cytoreduction and complications. Gynecol Oncol 2018;149:263-9.

46. Cianci S, Rumolo V, Rosati A, et al. Sarcopenia in Ovarian Cancer Patients, Oncologic Outcomes Revealing the Importance of Clinical Nutrition: Review of Literature. Curr Pharm Des 2019;25:2480-90.

47. Cianci S, Tarascio M, Rosati A, et al. Sexual function and quality of life of patients affected by ovarian cancer.

Cite this article as: Uccella S, Franchi MP, Cianci S, Zorzato PC, Bertoli F, Alletti SG, Ghezzi F, Scambia G. Laparotomy $v s$. minimally invasive surgery for ovarian cancer recurrence: a systematic review. Gland Surg 2020;9(4):1130-1139. doi: $10.21037 / g s-20-353$
Minerva Med 2019;110:320-9.

48. Cianci S, Abatini C, Fagotti A, et al. Hyperthermic intraperitoneal chemotherapy (HIPEC) for peritoneal malignancies using new hybrid $\mathrm{CO} 2$ system: preliminary experience in referral center. Updates Surg 2019;71:555-60.

49. Petrillo M, De Iaco P, Cianci S, et al. Long-Term Survival for Platinum-Sensitive Recurrent Ovarian Cancer Patients Treated with Secondary Cytoreductive Surgery Plus Hyperthermic Intraperitoneal Chemotherapy (HIPEC). Ann Surg Oncol 2016;23:1660-5.

50. Gallotta V, Giudice MT, Conte C, et al. Minimally invasive salvage lymphadenectomy in gynecological cancer patients: A single institution series. Eur J Surg Oncol 2018;44:1568-72.

51. Gallotta V, Bruno M, Conte C, et al. Salvage lymphadenectomy in recurrent ovarian cancer patients: Analysis of clinical outcome and BRCA1/2 gene mutational status. Eur J Surg Oncol 2020;46:1327-33.

52. Giampaolino P, Della Corte L, Foreste V, et al. Unraveling a difficult diagnosis: the tricks for early recognition of ovarian cancer. Minerva Med 2019;110:279-91. 